\title{
Urban design—or lack thereof-as policy: the renewal of Bursa Doğanbey District
}

\author{
Bülent Batuman' ${ }^{1} \cdot$ Feyzan Erkip $^{1}$
}

Received: 31 March 2016/Accepted: 28 January 2017/Published online: 10 February 2017

(C) Springer Science+Business Media Dordrecht 2017

\begin{abstract}
The role of urban design in urban policy making has been extensively discussed in recent years due to the insufficiency of existing applications in the complex structure of global urbanization. This paper aims at addressing the role of urban design as a policy instrument in urban politics through a case in one of the metropolitan cities of Turkey, Bursa. The case presented in the article reflects the emergence of a non-space in a city with a rich historic and cultural heritage. Lack of control and accountability, lack of communication between actors in the process and power coalitions are the main reasons of this process that caused the huge misfit between TOKI Doganbey settlement and the overall context. This settlement harmed Bursa's identity tremendously and caused a lot of turmoil since none of the parties involved is content with the end product. We try to elaborate on the process and the role of various actors in shaping it. Turkey does not have a rich urban design experience although successful projects are seen in high-income housing settlements. We conclude that it is timely to start with a new approach to the discipline to prevent such failures with large impacts on the urban form and life. The need for a holistic approach seems imperative to establish the core of a new urban design discipline involving socio-spatial concerns.
\end{abstract}

Keywords Urban design · Urban policy · Bursa · TOKI · Turkey

This paper aims at addressing the role of urban design as a policy instrument through a case in one of the metropolitan cities of Turkey, Bursa. Currently, a major industrial center, Bursa has a rich history particularly due to its role as the capital city of the Ottoman Empire in the fourteenth century. The city's legacy as a historic and religious center continues to attract domestic and foreign tourists. These characteristics are reflected in the

Bülent Batuman

batuman@bilkent.edu.tr

Feyzan Erkip

feyzan@bilkent.edu.tr

1 Department of Urban Design and Landscape Architecture, Bilkent University, 06800 Ankara, Turkey 
rich public architecture of the city, mostly characterized by mosques, külliyes, khans and cemeteries. Traditional forms of retail spaces and housing settlements are main components of Bursa's urban identity. The buildings from the republican period in the first half of the twentieth century also display architectural identity reflecting their period. ${ }^{1}$ Despite changes in recent years, the city protected its dominant architectural patterns, most of which were recognized as UNESCO world heritage sites.

The major topic of the paper is the renewal of a particular district within such a historical city embodying architectural richness. The case that will be discussed below concerns Doğanbey District, a run-down quarter with a central location quite close to the historic core. The area was dominated by old houses and industry, and with the involvement of the Mass Housing Administration (TOKI), it was subject to a swift process of slum clearance and the construction of new housing units. Nevertheless, the striking outcome was disastrous in terms of urban quality: 23 densely located blocks with 23-floor height now rise in downtown Bursa, dominating the skyline (Fig. 1).

Today, the Doğanbey renewal project is regarded as one of the biggest failures by almost all parties including the government officials responsible for its realization. Our intention in this paper is to scrutinize this case of failure with regard to the role of urban design. The renewal process involved various public and private actors as TOKI works with local contractors to build the houses. Within this framework, planning regulations, government intervention and power relations, the level of opposition and consent are key topics to be discussed in order to understand the true nature of the resulting product, a settlement that is completely inconsistent with the overall spatial quality of the historical city. To understand the nature of the process that resulted in such an architectural and spatial failure, we ask the following questions: "What are the existing mechanisms of planning that make such non-place possible?" "Is there a missing link between planning and architecture and if so, what are the mechanisms that help to make the process healthier?" "Can urban design be defined as one of the links needed? Could it provide an effective frame of reference for a successful negotiation process?"

\section{The renewal of Bursa Doğanbey District}

Urbanization in Turkey has followed a pattern similar to the developing nations of the Third World in the postwar era. It comprised clientelist policies subsuming the immigrant populations into the urban realm. This pattern later gave way to a second phase across the globe, which depended on "new entrepreneurialism" seeking participatory governance methods. The peculiar form of this phase in Turkey rested on amnesties legalizing squatter areas surrounding the major cities (Eraydın and Taşan-Kok 2014). Local improvement plans allowing building heights up to 4-5 floors not only transformed the physical textures of the Turkish cities but also turned squatters into landlords and developers undertaking the redevelopment of their neighborhoods. While the increasing dominance of local improvement plans represented the decline of comprehensive planning in Turkey, they also created a sort of "entrepreneurial subjectivity" transforming the squatters as urban political actors. $^{2}$ The fragmentary development of Turkish cities disregarding macro-decisions opened up the path to the deployment of urban design projects as a means of urban growth

\footnotetext{
${ }^{1}$ For architectural identity in Bursa, see Birlik (2011).

${ }^{2}$ Karaman (2014) uses the term in reference to the current urban regeneration projects in Turkey, but this particular form of subjectivity has its roots in the 1980s.
} 


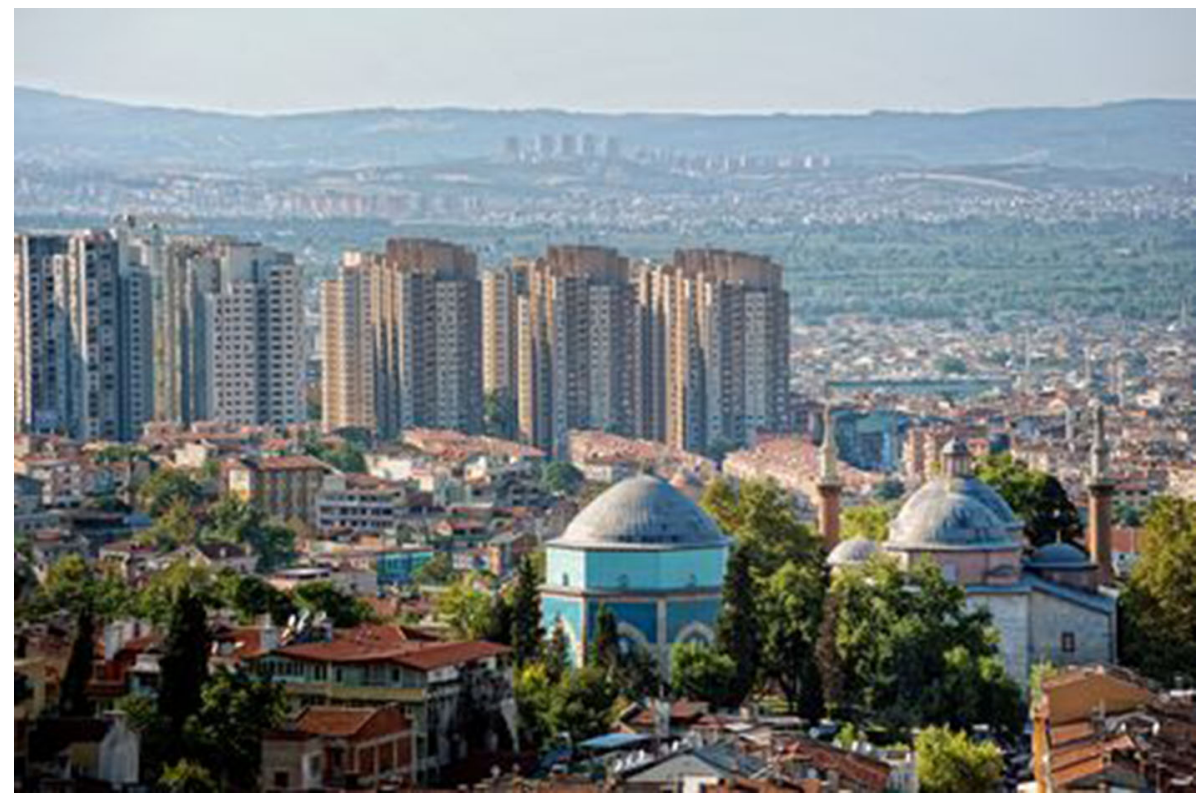

Fig. 1 TOKI Doğanbey high-rises dominating Bursa's skyline (Source: http://konuttimes.com/toki/tokibursagursu-basvuru-donemi-bugun-basladi/72815)

in the following decade. As we will discuss shortly, both this method and this particular form of subjectivity were important in the regeneration of Doğanbey.

Continuous population growth was inevitably coupled by the constant need for housing production. TOKI was established in 1984 to this end, with the objective of providing lowincome citizens with proper housing to remove squatter settlements. The administration initially funded housing cooperatives, which resulted in the use of its resources to support middle-class housing rather than the urban poor (Tekeli 1996). In 2003, TOKI was granted new powers. Accordingly, it was allowed to establish companies, execute projects to create new funds, and use public land without charge. In 2004, it was granted planning authority in the regeneration sites and the power to determine the value of expropriation in squatter areas. In 2007, the duties of the Ministry of Public Works regarding slum clearance were also transferred to TOKI. With these regulations, the administration became exempt from almost all of the bureaucratic mechanisms and could freely expropriate, plan and redevelop areas. Moreover, it became the major actor in housing production and the main facilitator of public private partnership. In inner city areas, TOKI undertakes the appropriation of multi-parceled land without legal obstacles or popular resistance and creates an investment-friendly environment. Land is appropriated under its market value, which provides enormous advantages for the developers in reducing costs. Using its administrative power to evaluate land lower than the market price, TOKI acts as a monopoly and mobilizes public-private partnerships (Rawlins 2013). ${ }^{3}$

\footnotetext{
3 As a result, the number of houses constructed by TOKI between 2003 and 2016 reached 700 000, while this number was merely 43,000 for the period 1984-2003 (TOKI 2011a, b, 2016). The figure given by TOKI includes apartments currently under construction; the number of houses actually delivered to their owners is 588221 (TOKI 2016).
} 
If we turn to Bursa within this framework, currently the fourth largest city of Turkey, it has always been an important settlement throughout history with its location on the Silk Road. Settled at the foot of Mt Uludağ (the Mysian Olympus) and overlooking the fertile Bursa Plain on the north, the city was famous for silk production during the Ottoman Empire and evolved into a commercial center for textiles. It was also one of the earliest industrial centers that emerged in Anatolia in the nineteenth century (Kaygalak 2008). Hence, it was also promoted by the republican elite seeking modernization and industrialization after the foundation of the nation state in 1923 . Similar to other major cities, Bursa experienced rural-to-urban migration in the postwar era; moreover, what was peculiar to Bursa was international migration particularly from Bulgaria which continued well into the 1990s. ${ }^{4}$ While the city expanded to the west with middle- and high-income residential areas, the low-income newcomers settled at the eastern edges.

The urban sprawl, particularly the relocation of middle- and high-income groups in the newly developing residential areas in western Bursa, led to the decline of various inner city quarters previously occupied by residential and/or small-scale production functions. A research comparing eight cities in Turkey found out that Bursa has the highest demand for housing in the city center which makes production here more attractive for private companies (Türel 2011). The share of private companies in total housing production in Bursa is above $90 \%$, and the growth rate of housing prices in Bursa is one of the highest in Turkey (TOKI 2011b).

The revitalization of the center was a strategic issue for Bursa, since tourism was conceived as an important sector. The city was selected among others for the City Branding project in 2009 as a part of tourism strategies by the Ministry of Culture and Tourism. ${ }^{5}$ Local power groups seem to have a consensus on the components of the new city brand involving the rich history of Bursa to create a potential for culture tourism. ${ }^{6}$ International organizations also have an agenda for sustainable development in Bursa among other Turkish cities (World Bank 2015). Thus, the prospect for urban transformation in Bursa has been a hot topic.

Within this context, the area under discussion, which was later labeled as Doğanbey Urban Renewal Zone, included the four neighborhoods of Doğanbey, Tayakadın, Kiremitçi and Kircaali and covered 180,000 square meters of very valuable land at the heart of Bursa (Fig. 2). The area contained 1-2 floor detached buildings in poor conditions. There were about 1250 dwellings aged between 70 and 80 (TOKI 2011b). The proximity of the area to the historic core of Bursa led to its designation as a new CBD in 1993. According to the development and land-use plans, the commercial functions within the historic center would expand to this area relieving the pressure on the historic zone and allow it to obtain a touristic character. However, although the perimeter of the area facing the major thoroughfares developed into commercial strips, the interior further degraded into slums. ${ }^{7}$ To the dismay of the development plans that foresaw the transformation of individual lots with building permits for 4-5 floors, contractors did not find it profitable to undertake construction in the area.

\footnotetext{
${ }^{4}$ For a historical account of Bursa's urban development, see Karakurt Tosun (2007: 106-126).

5 For the City Branding Project, see Gündoğdu (2014).

6 For Bursa's urban identity as perceived by its citizens, see Taşkın and Tuncel (2011). For urban coalitions in Bursa, see Tunç (2011).

7 For a detailed account see, Uyan (2008: 150-155).
} 


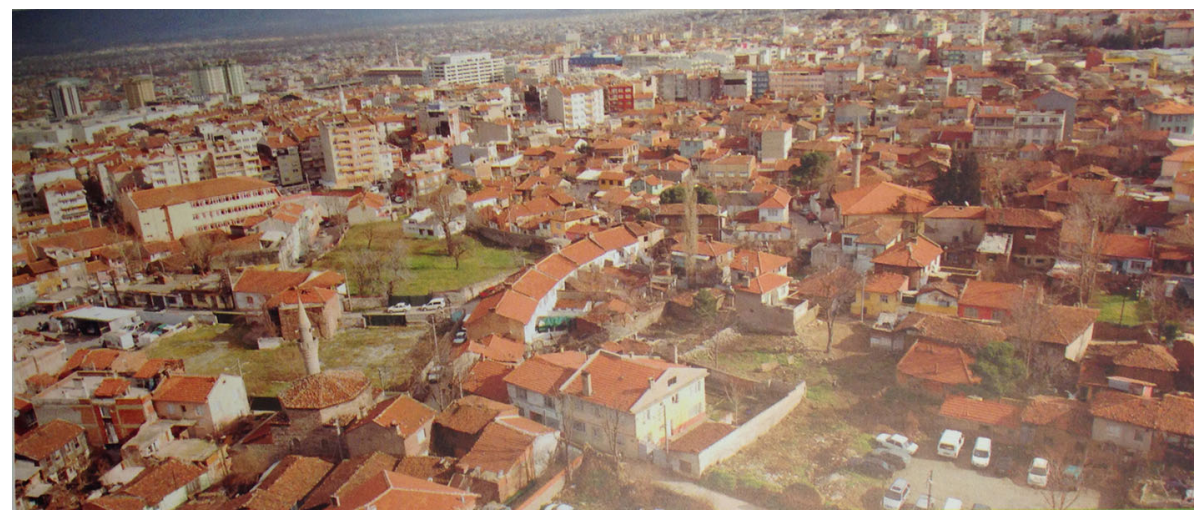

Fig. 2 Doğanbey urban renewal zone before the process (Source: TOKI 2011c, p. 119)

With the emergence of a new urban renewal paradigm empowering TOKI and the municipalities, Osmangazi Municipality, which operates in the central part of the city containing the historical core, took initiative. Although the municipality lacked authority and know-how to implement a renewal project, the mayor effectively mobilized local power groups (organized in the chambers of commerce and industry) and was successful in gaining the support of one of the ministers who was elected to the parliament as Bursa representative. With the involvement of Minister Çelik, TOKI came into the picture. The district municipality signed a protocol with TOKI in early 2006 (Uyan 2008). By the end of the year, Bursa Greater Municipality also became a stakeholder in the protocol, since urban renewal powers were granted to the greater municipalities. The greater municipality transferred its authority to the district municipality via this protocol. Since it is not common to see a greater municipality giving up its authority in urban renewal (which is extremely profitable within the existing legal framework), this is a proof of the power of the urban coalition mobilized by the mayor of Osmangazi District. The district municipality acquired the service of a consultancy firm (Öncü Mimarlık) in producing the analyses regarding ownership pattern in the area. These analyses revealed that there were 4300 shareholders on 1000 houses and $98 \%$ of these consented to the project (Osmangazi Municipality 2008). With the consent of the majority and the expropriation of the remaining lots, evacuation of the area and the demolition of existing buildings started in 2007. Table 1 shows the stages of the process, which represents the typical method deployed by TOKI. The significant aspect of the process is the minor role given to participation, which is understood merely as informing the inhabitants. The major actors are defined as TOKI and the municipality, and these two actors define the terms of agreement for the part of the inhabitants without any deliberation with them. The inhabitants are informed after the preparation of 1/1000 urban design blueprints, that is, the residents do not have a say in either the terms of agreements or the physical design of the housing environment. It is also crucial to note that urban design is understood as the physical layout representing the land-use organization based on the economic model.

Initially, Öncü Mimarlık was authorized to achieve the concept design for which a private urban design firm (Tektonika) was hired. The preliminary proposal dated February 2007 contained variety of building types and unit sizes (Table 2). Although the initial idea was to provide an apartment for each shareholder, the divergence between the numbers of existing houses and that of the shareholders led to the definition of a benchmark limit to be 
Table 1 Pre-construction stages of urban renewal in Doğanbey, Bursa

\begin{tabular}{|c|c|}
\hline Project stage & Explanation \\
\hline Initial decision & Definition of the financial model and establishment of collaboration with TOKI \\
\hline $\begin{array}{l}\text { Legalization of the initial } \\
\text { decision }\end{array}$ & Designation of the area as an urban renewal zone by the Municipal Assembly \\
\hline Signing the agreement & Protocol between municipality and TOKI \\
\hline Analyses & Study and documentation of ownership pattern in the project area \\
\hline Economic model & $\begin{array}{l}\text { Study of maximum floor area to be built, definition of apartment sizes, contents } \\
\text { of the individual contracts }\end{array}$ \\
\hline Value assessment & Evaluation of the assets in the project area \\
\hline $\begin{array}{l}\text { Approval of value } \\
\text { assessment }\end{array}$ & TOKI approves value assessment studies \\
\hline $\begin{array}{l}\text { Hypothetical urban } \\
\text { design scheme }\end{array}$ & Delineation of physical sizes (built area) derived from the economic model \\
\hline Urban design proposal & $1 / 1000$ blueprints indicating massing \\
\hline Preparation of contracts & Preparation of individual contracts to be signed by the shareholders \\
\hline $\begin{array}{l}\text { Agreement with } \\
\text { shareholders }\end{array}$ & Acquiring the approval of the shareholders \\
\hline $\begin{array}{l}\text { Municipal approval } \\
\text { (contracts) }\end{array}$ & Municipal Assembly approves details of contracts \\
\hline $\begin{array}{l}\text { Municipal approval } \\
\text { (masterplan) }\end{array}$ & Municipal Assembly approves $1 / 5000$ masterplan \\
\hline $\begin{array}{l}\text { Bids for urban design } \\
\text { project }\end{array}$ & Bids for $1 / 1000$ revision plan and the urban design proposal \\
\hline $\begin{array}{l}\text { Municipal approval } \\
\text { (1/1000 plan) }\end{array}$ & Municipal Assembly approves $1 / 1000$ revision plan \\
\hline Parcellation plans & Bids, preparation and approval of parcellation plans \\
\hline $\begin{array}{l}\text { Architectural concept } \\
\text { project }\end{array}$ & 1/200 Site plan \\
\hline
\end{tabular}

Produced from TOKI (2011b: 113)

Table 2 Building types and unit sizes in various proposals for Doğanbey Renewal Project

\begin{tabular}{|c|c|c|c|c|}
\hline & February 2007 & Late 2007 & February 2008 & April 2008 (final) \\
\hline $75 \mathrm{~m}^{2}$ & 880 & 840 & 898 & 1147 \\
\hline $112 \mathrm{~m}^{2}$ & 807 & 683 & 666 & 624 \\
\hline $150 \mathrm{~m}^{2}$ & 880 & 884 & 932 & 976 \\
\hline Total number of units & 2567 & 2407 & 2496 & 2747 \\
\hline $\begin{array}{l}\text { Low-rises courtyard } \\
\text { type ( } 3-4 \text { floor) }\end{array}$ & 550 units & 498 units & 430 units & 430 units \\
\hline Mid-rises & 6 floor row blocks & $\begin{array}{l}6-9 \text { floor row } \\
\text { blocks }\end{array}$ & $\begin{array}{l}14 \text { floor } 7 \\
\text { detached blocks }\end{array}$ & - \\
\hline High rises & $\begin{array}{l}17 \text { towers, } 18-19 \\
\text { floors }\end{array}$ & $\begin{array}{l}16 \text { towers, } 17-21 \\
\text { floors }\end{array}$ & $\begin{array}{l}16 \text { towers, } 18-23 \\
\text { floors }\end{array}$ & $\begin{array}{l}23 \text { towers, } 18-23 \\
\text { floors }\end{array}$ \\
\hline
\end{tabular}

Produced from Nalbant (2011) 
eligible for a house in the project and equivalence between the existing shares and the future ones $\left(75-\mathrm{m}^{2}\right.$ apartment for $50-\mathrm{m}^{2}$ plot share). Determined to organize a renewal process keeping the residents in the area, the consultants proposed to entitle each resident holding a share of $5 \mathrm{~m}^{2}$ to own a house with a mortgage to be paid in 10-12 years (interview with consultants in Öncü Mimarlık, 07.12.2016). After calculations based on the negotiations with the shareholders (more than half owned shares smaller than $50 \mathrm{~m}^{2}$ ), 2400 units were allocated to the shareholders (TOKI 2011b), that is, nearly half of the shareholders either chose to leave the project area not being able to afford the proposed loans or signed agreements jointly. The apartments were promised to be finished in 18 months, and the shareholders were to be provided with rent aid during the construction period. TOKI was to own a commercial lot of $15,000 \mathrm{~m}^{2}$ allocated for a shopping mall as well as a number of apartments. The district municipality and Bursa Commodity Exchange were also given shares in the project. $^{8}$

The design proposal displayed concern for the heights of surrounding buildings (Fig. 3). While high rises were situated closer to the commercial center and its busy streets with already high buildings, residential quarters with lower building heights were faced with low-rise houses. Moreover, the circular organization of the high-rises allowed for a central open space, which was organized around a number of registered structures-an old mosque, a dysfunctional bath and four adjacent traditional houses. TOKI officials argued that the variety in building types increased costs and demanded them to fit into simpler plan types to be produced via modular tunnel mold systems. The contract was nullified after the designer's decline to make concessions regarding architectural quality.

A new architectural office produced three successive proposals, each of which contained a higher number of units per instructions from TOKI (interview with the architect, 03.12.2016) (Fig. 4). The increase in the built area also brought about changes in the sizes of the units which meant alterations in already signed contracts between TOKI and the residents. The residents were outraged to learn that their houses were increased in size, which meant that their debt to TOKI was multiplied without their consent. The displeasure was further increased with the failure to finish construction on time and the disorganization in the payment of promised rent aid. Here a number of points are worth emphasis since they reveal the problems of the process. First, the contracts were signed individually and demolitions started in 2007. However, the final project was not achieved until April 2008. Interestingly, even the 2009 report of the Chamber of City Planners Bursa Branch, prepared in March, included the visuals of the initial project (2009: 63-65), that is, by early 2009 , neither professional organizations nor the residents were informed about the changes in the project. Second, the execution of the project was done in stages each of which was pursued by a different firm. Since the detailed projects were not achieved at the time of the bids, it was up to the subcontractors to have the detailed projects prepared. This, in return, gave them chance to manipulate the architects toward reducing costs, which is often the case in TOKI's renewal projects (Gür and Dostoğlu 2010).

2009 was an election year, in which the ruling AKP - controlling the central government as well as the district and metropolitan municipalities under discussion-used the project for propaganda. The mayor of Osmangazi Municipality ran for the greater municipality and won the post. However, after the elections the discontent of the shareholders grew. Soon they began to mobilize using social media and questioning the details of the project, which proved to be different than the initial one. In addition, the latitude

\footnotetext{
8 The fact that Bursa Commodity Exchange had a share in the project was only revealed once the organization waived its share later in the process.
} 

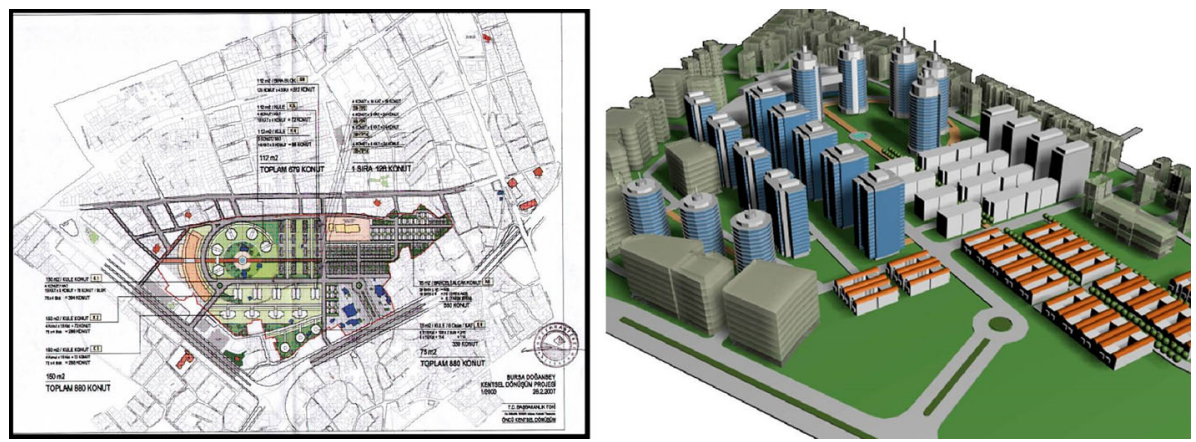

Fig. 3 Initial urban design proposal (Source: Nalbant 2011)

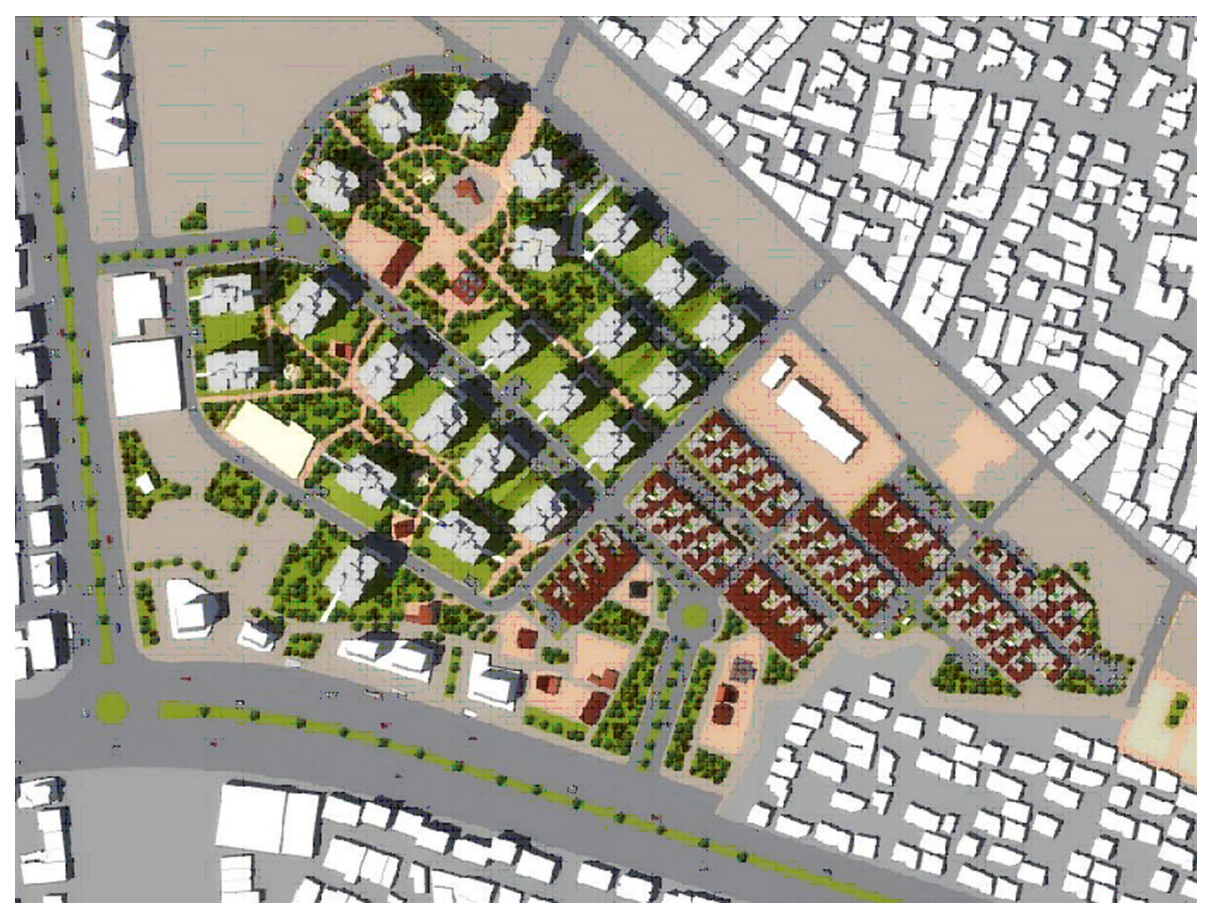

Fig. 4 Site plan of the final version (Source: Nalbant 2011)

given to the subcontractors resulted in low-quality materials and poor finishing. These problems only became visible after some of the residents managed to sneak into the construction site and uploaded photographs from the buildings under construction in early 2010 (tokidoganbey.com 25.01.2010). The residents' vocal protests led to lawsuits and petitions to which TOKI chose not to respond. However, once the structural frame construction was finished, both the misfit of the high-rises in the city's skyline and the lack of open space in the final organization were revealed.

The failures of the project can be summarized under a number of headings. First of all, the shareholders had economic complaints due to the three-year delay in construction 
process as well as the involuntary increases in floor areas of the apartments which meant unplanned increase in mortgage payments. Secondly, the social environment was worsened: The neighborhood relations significantly diminished within the high-rise blocks, and the residents complained about the misfit between the apartments and their daily activities. A recent field research has revealed that the social discontent in the housing compound is so high that it has generated negative psychological effects on individuals (Gür and Dostoğlu 2016: 98). Although it is not possible to directly relate them with negative environmental quality, it is worth mentioning here that there have been two cases of suicide attempts in the high-rises (Bursaport 09.07.2012; Bursadabugün 22.03.2016). Thirdly, the residents complain about architecture: They criticize the blocks for their excessive height and closeness as well as their negative effect on the city silhouette (Gür and Dostoğlu 2016: 102). The low quality of construction is frequently voiced by the residents, and the constricted open spaces in between the towering high-rises do not generate social interaction. Perhaps, the most interesting observation is the complaint of the residents regarding the lack of safety in the housing compound with its central location in the city. According to research findings, the residents refrain from using the underground parking lots for fear of security and request walls to enclose the compound (Gür and Dostoğlu 2016: 104). While the residents are not happy with the quality of life in the compound, it is also not possible to say that the area is well connected to the historical center. The renewal of the area brought about traffic congestion by creating easy access to the center which previously was blocked due to narrow streets of the organic texture. Nevertheless, the area neither conforms to the commercial activities of its surrounding nor does it provide an impetus strong enough to transform its character.

In addition to the stakeholders' complaints, professional organizations criticized TOKI and the municipality for the shady process and took the matter to court. The Bursa branch of the Chamber of Architects organized a photography competition entitled "TOKI's Slap in the Face of Bursa", criticizing the project (Chamber of Architects Bursa Branch 2011). The opposition parties blamed the government for the failure. The government in return pointed at TOKI as the responsible organization. According to TOKI officials, the changes in the project were inevitable and due to the unforeseen composition of the shareholders (interview with the head of TOKI's urban renewal department, 12.11.2015). TOKI Director Ergün Turan claimed that it was the failure of the architects who could not produce quality design and that there were no talented architects in Turkey (haberler.com, 29.03.2015). The public pressure on the government became even more serious toward 2011 , in which the general elections were to take place. This time, the organized stakeholders utilized the upcoming elections as a leverage to gain concessions. With directives of the Prime Minister, TOKI canceled $30 \%$ of the overall debt; meanwhile, the district municipality renounced its share of 35 units, and the Bursa Commodity Exchange also gave up $1 / 3$ of its share. These negotiations helped ease the shareholders' outrage and allowed the AKP to maintain its vote rates in 2011 elections. Nevertheless, the damage to the urban tissue and its social and economic environment prevailed (Fig. 5).

\section{Urban design as a tool/remedy for a holistic approach}

The empowerment of TOKI represented a particular strategy of urban development in Turkey, where the government eagerly supported the expansion of construction activity. Legislation changes promoting real estate and construction investments followed one 


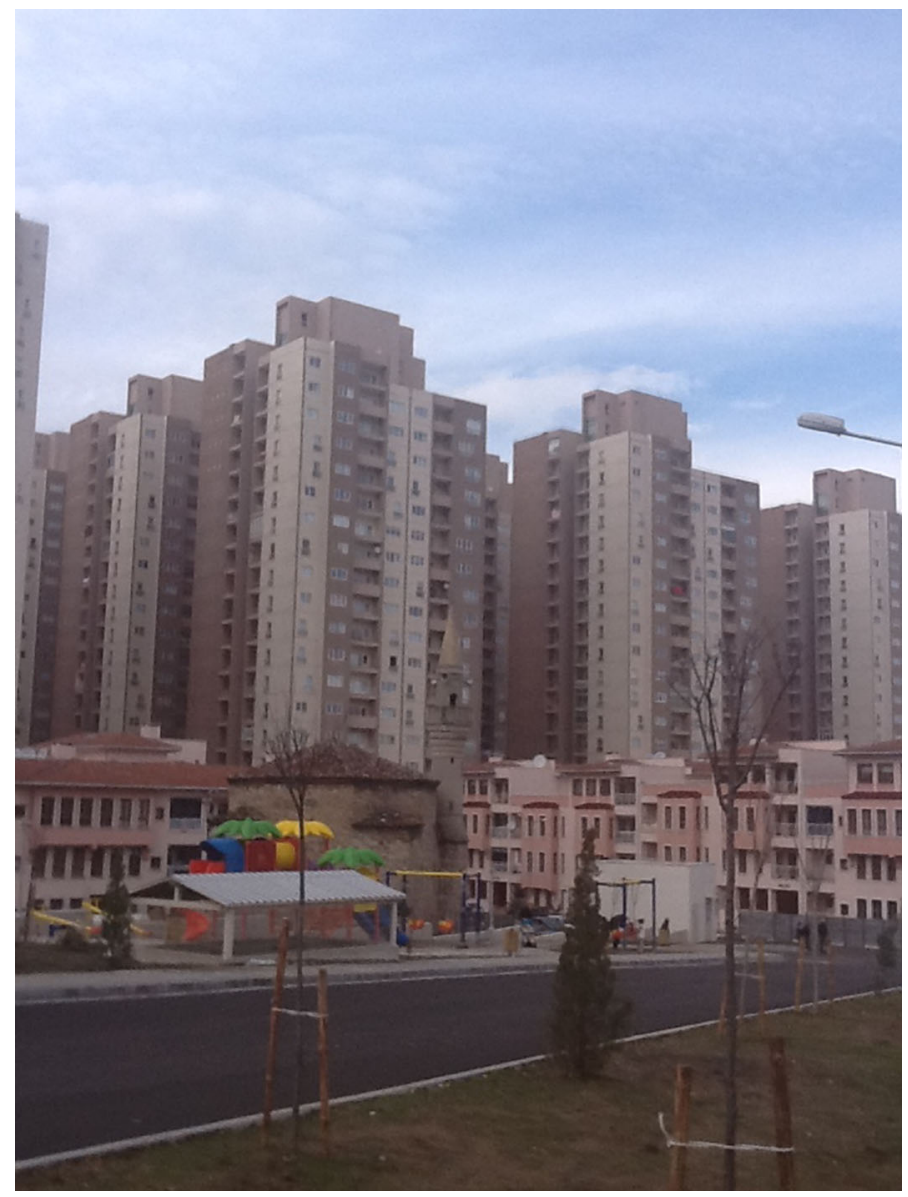

Fig. 5 Current view from the site (Source: Authors)

another after 2004. These changes aimed at the deregulation of the legal and institutional framework of urban planning and existing bureaucratic control mechanisms over development (Balaban 2012). The outcome was increased autonomy for developers in private sector as well as TOKI itself, which from then on acted as a profit-oriented actor (Özdemir 2011; Batuman 2013). Land-use plans were revised and/or renewed to encourage marketdriven redevelopment. Here, urban design was deployed as an instrument to achieve piecemeal projects, to which the plans were later adapted. As we have pointed out above, the stages of the renewal process in Doğanbey reveal the role defined for urban design within TOKI's renewal mechanism. Here, it is reduced to the physical expression (massing) of the economic model and developed without any deliberation with other stakeholders. Contrary to its current practice in Turkey, we argue that urban design can and should serve as a key instrument to develop a holistic approach to the process of urban regeneration, which, rather than prioritizing profit, should be understood as a comprehensive action in the face of urban decline (Roberts and Sykes 2000).

Urban design has assumed an increasingly dominant role in place-making parallel to the global commodification of urban space (Hubbard 1996; Carmona et al. 2002; Madanipour 
2006). Cities competing for investments are turning to urban design as a major instrument (Gospodini 2002). Within this context, the quality of urban space emerges as an important concern. Here, quality simultaneously signifies two different aspects which do not necessarily conform to each other: livable environments and user-friendly spaces, and suitable conditions for investments requiring disciplining of labor. This dual aspect brings into question the ideological character of urban design (Gunder 2011). The question here is whether or not urban design can reconcile the social and economic interests.

Madanipour (2006) has analyzed the reasons of the increasing importance of urban design in the last decade and stated that when the state becomes a regulatory institution, urban design becomes a more private action dealing with larger-scale investments as a part of economic rationales. Carmona et al. (2002) have also emphasized the regulatory role of the public sector in providing incentives and setting barriers in the process. Coordinating urban development, reducing uncertainties and risks with a better allocation of resources in the city and securing the value of property are main roles of urban design. This brings us to the question why TOKI (a central state institution) is involved in the production of new settlements, if not for regulating the development of such areas. It is understandable that short-term business cycles put a pressure on city-building to make it faster and to increase the exchange value. In such cases, the state is expected to control the quality of the process and the product to increase the use value.

Urban design as an integral part of the urban development process requires the building of a coalition among various actors to arrive at a consensus on the new city image, which consists of a blend of the past, present and the future (Hubbard 1996). A well-designed environment is positively evaluated by all parties, including developers, investors and occupiers: "the rationales for each stakeholder's views on the value of the design (which determines how much they are prepared to invest in it) are mediated by the nature of the system of interaction among those stakeholders, determined by the planning system, market regulations, and so forth" (Carmona et al. 2002, p. 149). ${ }^{9}$ Participative approaches have often resulted in sustainable environments achieved through democratic decisionmaking processes.

Childs (2010, p. 15) claims that "urban fellows" are one of the main components in such debates and "collaborative networks of urban fellows may include: (1) place-based networks, (2) professional networks and (3) governmental networks". Although all these parties took part in the renewal of Doğanbey, the result is not satisfactory for any of the parties precisely because a participation mechanism was not defined. ${ }^{10} \mathrm{~A}$ crucial point that differentiates Doğanbey case from other TOKI projects is that the area was not a peripheral squatter settlement but an inner city area with splintered ownership, which had two major consequences. The first is the relative height of the rent gap in the renewal area, and the second is the lower-middle-class character of the shareholders which makes them inclined to display an entrepreneurial subjectivity discussed earlier. While the squatters living in areas subject to regeneration are individually more vulnerable due to their limited legal rights on land, they display varying levels of solidarity in defending their living environments - their only possession in the urban realm. Doğanbey residents, in contrast, were not desperately attached to their environment and saw opportunities of economic gain in

\footnotetext{
${ }^{9}$ Here, it is worth mentioning that there are counter arguments as well. For instance, Raco and Imrie (2000) have argued that "technologies of government" as a set of mechanisms, regulate and monitor actions of all the actors in the local development process toward the expected end by the government. Thus, "active citizen" and policy-making communities turn out to be another tool of government rationality.

10 TOKI organized an event in 2011 to assess its errors in urban regeneration. See TOKI (2011d).
} 
the project. Nevertheless, lack of participation in the process became a serious problem for TOKI with this kind of stakeholder profile when discontent with the enforced increases in mortgage payments began to gain an organized character threatening the upcoming election results. Hence, TOKI had to use the only means available, which was to raise the rent to allocate some portion of it to the stakeholders by increasing the built floor area. Thus, the lack of participation which generally is beneficial to TOKI and the municipalities in controlling the residents in a designated renewal zone has counterworked in the case of Doğanbey, leading to a populist form of negotiation.

We strongly believe that urban design is a key instrument to define terms of participation and it should be a vital part of such large-scale projects, especially when they have an impact on the urban context. It is certain that the benefits from exchange value would increase with a better urban design and this is the selling point of more esthetic and sustainable developments. Yet, in Doğanbey, the treatment of stakeholders as atomized actors rather than a collective agent has led to their identifying with single apartments instead of perceiving the total environment of the housing project. Here, we arrive at the problem of architecture, or the quality of the built environment. Although TOKI's housing estates are generally criticized for their lack of concern for the context, none has been so disastrous as Doğanbey. ${ }^{11}$ Moreover, TOKI's revenue-sharing projects in luxury housing are all marketed with an emphasis on architectural elegance. Apparently, know-how and competent designers are not what the process lacks.

A new urban image, even if it contradicts with local heritage, might be a source of civic pride and solidarity if it is embraced by citizen groups. Innovative design may boost both exchange and use values of new urban spaces. Madanipour (2016) defines this as experimental urban design, which helps promoting and branding the city. In Doğanbey case, symbolic value, collective memory, identity and pride are ignored together with architectural identity. This is particularly significant for the AKP in power, since the party identifies itself with the Ottoman past as a representation of a nationalist image defined primarily by Islam (Batuman 2016).

In Doğanbey, the failure to identify the housing compound as a living environment for residents and the focus on individual apartments as commodity has led to the overlooking of the economic surplus that could have generated with a better design. As Gunder (2011, p. 191) has rhetorically asked, "How could someone not want to live in a beautiful place of efficient urban form that provides a high standard of livability? Indeed, this should be a universal planning goal... But, and this is a big BUT, beauty, form, and livability must not be blindly produced by practitioners at an inequitable cost to other residents or exploited labor, or, especially, at the cost of environmental degradation." Thus, an optimization of components including beauty, user comfort and satisfaction is required, where urban design may serve to mutual benefit rather than irreconcilable opposition between exchange and use values.

\section{Conclusion}

In this article, we analyzed the mechanisms and processes of building a non-space with a drastic case asking questions on interested parties, lacking tools and communication gaps between various actors. In Doğanbey case, neither public nor private benefits are satisfied as far as the citizens buying and living in the houses are concerned. Particularly in Bursa,

11 See, for example, the cases presented in TOKI (2011c). 
TOKI settlement creates a problem for city branding and sustainability issues, indicating that even the neoliberal policies are overridden by the investors, developers and public authorities. "Responsive cohesion," as applied by Radford (2010) to urban design decisions, seems one good and timely suggestion for future urban design processes. To set ethical foundations and boundaries of urban design practices, it needs to be beneficial for all parties involved. Bursa's identity is damaged tremendously by the misfit between TOKI Doğanbey and the overall context. Seemingly, the dominating factor in urban design practice of Turkey is economic benefit and it constitutes the foundation of related decisions. Yet, the Bursa case illustrates the loss of economic rationale due to lack of communication and accountability, which led to a failure to establish long-term power coalitions.

It is crucial to note the difference between construction in a vacant lot and a dense tissue in the urban core of a historic city such as Bursa. In the first case, architecture may enhance or restrict the life of the inhabitants only, whereas in the latter it is also a stain in the urban context. Thus, a successful urban design is crucial along a successful architecture. We might consider the settlement partly a public space due to its central location, both for its inhabitants and other citizens either passing through or viewing it from a distance. This issue of publicness is very much related to esthetical values and needs to be discussed from an urban design viewpoint. Thus, we think that the effect of the built environment-an edifice or a settlement-in the city is threefold: its collective use as a public good, its façade and physical features as an esthetic component of the city and its economic impact on the inhabitants and citizens. This understanding necessitates a thorough analysis of the context, in terms of economic and social relations and space characteristics before and after the production process.

TOKI as a state institution should claim responsibility for the end product in all respects including esthetic and environmental issues, utilizing urban design as a strong ally in the process. Controlling the process and creating harmony between all interested parties can only be provided by a public institution. As illustrated by our discussion on Doğanbey, Bursa, urban design practice in Turkey is not holistic and requires redefinition. This situation may be seen as an opportunity to make a fresh start for building a more effective discipline, which is inspired by recent debates on urban design. Assuming that this is the intention, a paradigm change in urban planning and design in Turkey is required; "a culture shift" is needed to make urban design "a long-term concern for governing authorities and property developers" (White 2015, p. 345). As suggested by LoukaitouSideris (2012, p. 476), "expanding urban design's scope and perspective" to involve everyday life of all citizens should be one of the first steps.

Finally, it is worth reflecting on how to deal with the disastrous environment created in the center of Bursa. Doğanbey compound can be used as a living laboratory for the purpose of creating a place from a non-place, since failed attempts at urban renewal in Turkey are not limited to this case. The site should be analyzed by a group of expert urban designers in collaboration with local planning bodies with respect to esthetic concerns and urban identity components. Feedback from shareholders and interested citizen groups should also be taken into consideration this time. Afterward, local and central government authorities might decide on the cost of intervention by urban designers to make the settlement a viable and appealing environment for users and citizens. Public funds by TOKI should be used to transform this non-space into a living laboratory to set a good example for the future developments in other cities.

The analysis of the process in Doğanbey leads us to the following strategies to prevent future failures: 
- Making urban design a part of planning process through laws and effective control mechanisms is needed at the macro-level. TOKI seems to be the appropriate public institution to provide this service instead of realizing the construction process. It should work as an intermediary between investors and the public rather than functioning as a private actor as was the case in Doğanbey. Urban design directed by a powerful public institution guarantees attention to public benefit.

- In Doğanbey case, urban design efforts were ignored for financial reasons. Yet, promoting urban design as a selling point for investors and developers may help see urban design as a necessary component. Thus, urban design can also serve economic interests emphasizing the value of the produced environment as a whole rather than the single apartments as commodity.

- Urban design can also provide a framework for participation on levels of decision making as well as design. Defining the development phases with feasible and shortterm benefits for developers and investors, and informing the public about long-term benefits help create a positive attitude toward the project from all parties. Informing all actors on a regular basis with participatory methods reduces the potential of conflict that has created a lot of problems in Doğanbey case.

- Participation can also be extended to the stage of physical design, where participatory urban design further encourages identification with the housing environment as residents.

- Increasing accountability and transparency which were missing in Doğanbey renewal process should also be taken into consideration as a function of public authority.

These suggestions do not necessarily work separately and hierarchically; considering them as the components of a holistic planning and design is more effective and applicable. Creating and utilizing mechanisms of such a system, however, is far harder and timeconsuming. ${ }^{12}$ However, this is necessary in order to implement urban design in specific cultural and institutional contexts.

\section{References}

Balaban, O. (2012). The negative effects of construction boom on urban planning and environment in Turkey: Unraveling the role of the public sector. Habitat International, 36, 26-35.

Batuman, B. (2013). City profile: Ankara. Cities, 31, 578-590.

Batuman, B. (2016). Architectural mimicry and politics of mosque building: Negotiating Islam and Nation in Turkey. The Journal of Architecture, 21(3), 321-347.

Birlik, S. (2011). Bursa'nın Mimari Kimliği. In H. Ertürk, N. Dostoğlu, N. Sam (Eds.) Cumhuriyet Döneminde Bursa'da Kentleşme Sempozyumu 22-23 Eylül Bildiriler Kitabı (pp. 215-230).

"Bursa'da 7. Kattan Atlamaya Kalkan Genci Polis Kurtard1,” Bursadabugün, 22.03.2016. http://www. bursadabugun.com/haber/bursa-da-7-kattan-atlamaya-kalkan-genci-polis-kurtardi-667843.html. Accessed 27, 2016.

Carmona, M., de Magalhaes, C., \& Edwards, M. (2002). Stakeholder views on value and urban design. Journal of Urban Design, 7(2), 145-169.

Chamber of Architects Bursa Branch. (2011). "Bursa'daki TOKI Konutları", unpublished report. Retrieved March 06, 2016, http://www.bursamimar.org.tr/ckfinder/userfiles/files/BURSADA\%20TOK\%C4\% B0\%20KONUTLARI\%20MAKALE.pdf.

\footnotetext{
12 See, for example, Cooper and Boyko (2010) for effective decision-making processes in various urban design projects. Palermo and Ponzini (2012) further exemplifies how urban development could be supported with appropriate urban design tools and strategies.
} 
Chamber of City Planners Bursa Branch. (2009). "Bursa Kent Raporu 2009”, unpublished report available online. Retrieved March 06, 2016, http://www.spo.org.tr/genel/bizden_detay.php?kod=840\&tipi= 2\&sube $=3 \#$.VtsZmX2LTDc.

Childs, M. C. (2010). A spectrum of urban design roles. Journal of Urban Design, 15(1), 1-19.

Cooper, R., \& Boyko, C. (2010). How to design a city in five easy steps: Exploring VivaCity2020's process and tools for urban design decision making? Journal of Urbanism: International Research on Placemaking and Urban Sustainability, 3(3), 253-273.

Eraydın, A., \& Taşan-Kok, T. (2014). State response to contemporary urban movements in Turkey: A critical overview of state entrepreneurialism and authoritarian interventions. Antipode, 46(1), 110-129.

Gospodini, A. (2002). European cities in competition and the new 'uses' of urban design. Journal of Urban Design, 7(1), 59-73.

Gunder, M. (2011). Commentary: Is urban design still urban planning? An exploration and response. Journal of Planning Education and Research, 31(2), 184-195.

Gündoğdu, İ. (2014) "Bursa, Turkey's journey in becoming a European brand city”. The Global Grid June 2. Retrieved March 16, 2016, http://theglobalgrid.org/bursa-turkeys-journey-in-becoming-a-europeanbrand-city.

Gür, M., \& Dostoğlu, N. (2010). Bursa'daki Alt ve Orta gelire Yönelik TOKI Konutlarında Memnuniyet Araştırması. Uludă̆ Üniversitesi Mühendislik-Mimarlık Fakültesi Dergisi, 15(2), 139-153.

Gür, M., \& Dostoğlu, N. (2016). Bursa Doğanbey Üzerinden Kentsel Dönüşümde Yaşam Kalitesinin Tartış1lması. Megaron, 11(1), 89-105.

Hubbard, P. (1996). Urban design and city regeneration: Social representations of entrepreneurial landscapes. Urban Studies, 33(8), 1441-1461.

Karakurt Tosun, E. (2007). Küreselleşme Sürecinde Kentlerde Mekansal, Sosyal ve Kültürel Değişim: Bursa Örneği. Unpublished Ph.D. dissertation, Uludağ University, Bursa.

Karaman, O. (2014). Resisting urban renewal in Istanbul. Urban Geography, 35(2), 290-310.

Kaygalak, S. (2008). Kapitalizmin Taşrası: 16. Yüzyıldan 19. Yüzyıla Bursa'da Toplumsal Süreçler ve Mekânsal Değişim. İstanbul: İletişim.

Loukaitou-Sideris, A. (2012). Addressing the challenges of urban landscapes: Normative goals of urban design. Journal of Urban Design, 17(4), 467-484.

Madanipour, A. (2006). Roles and challenges of urban design. Journal of Urban Design, 11(2), $173-193$.

Madanipour, A. (2016). Ephemeral Urbanism. In Keynote speech given at Designing Urban Design: Towards a Holistic Perspective International Symposium., October 4-6, 2016. Ankara, Turkey: Middle East Technical University.

Nalbant, K. (2011). Doğanbey Kentsel Dönüşüm Projesi Mimari Projeler ve Uygulama Sonuçları. Unpublished document.

Osmangazi Municipality. (2008). Bursa Osmangazi Doğanbey Kentsel Dönüşüm Projesi Çalışma Raporu. Bursa: Osmangazi Municipality.

Özdemir, D. (2011). The role of the public sector in the provision of housing supply in Turkey, 1950-2009. International Journal of Urban and Regional Research, 35(6), 1099-1117.

Palermo, P. C., \& Ponzini, D. (2012). At the crossroads between urban planning and urban design: Critical lessons from three italian case studies. Planning Theory and Practice, 13(3), 445-460.

Raco, M., \& Imrie, R. (2000). Governmentality and rights and responsibilities in urban policy. Environment and Planning A, 32, 2187-2204.

Radford, A. (2010). Urban design, ethics and responsive cohesion. Building Research and Information, 38(4), 379-389.

Rawlins, J. R. (2013). From wheat fields to mass housing, Ankara's neoliberal conjuncture. Unpublished M.A. Thesis, Simon Fraser University.

Roberts, P., \& Sykes, H. (2000). Urban regeneration: A handbook. London: Sage.

Taşkın, Ç., \& Tuncel, C. O. (2011). Sürdürülebilir Kentsel Rekabet için Markalaşma: Bursa Kentinin Markalaşma Stratejilerinde öne Çıkan Faktörleri Belirlemeye Yönelik bir Araştırma. In Cumhuriyet Döneminde Bursa'da Kentleşme Sempozyumu 22-23 Eylül Bildiriler Kitabı (Der. Ertürk, H. Dostoğlu, N. and Sam, N.) (pp. 81-92).

Tekeli, İ. (1996). Yaşamda ve Yazında Konut Sorununun Gelişimi. Ankara: TOKI.

TOKI. (2011a). Building Turkey of the future: Corporate profile 2010/2011. Ankara: TOKI.

TOKI. (2011b). Kentsel Dönüşümde Model Arayışları. Ankara: TOKI.

TOKI. (2011c). Gecekondu Dönüşüm Kentsel Yenileme Projeleri. Ankara: TOKI.

TOKI. (2011d). 2011 Konut Kurultayi/Housing Convention 2011. Ankara: TOKI.

TOKI. (2016). “TOKI Konut Üretim Raporu,” 12.02.2016. Retrieved February 15, 2016, https://www.toki. gov.tr/AppResources/UserFiles/files/FaaliyetOzeti/ozet.pdf. 
“TOKİ Doğanbey’e Ayak Bastık,” tokidoganbey.com 25.01.2010, http://www.tokidoganbey.com/haber/ haber8.html.

“TOKİ Doğanbey'de 10. Kattan İntihar,” Bursaport, 09.07.2012. http://www.bursaport.com/haber/guncel/ polis-adliye/toki-doganbeyde-10-kattan-intihar-24549.html. Accessed 27, 2016.

“TOKİ Başkanı Turan Açıklaması,” Haberler.com, 29.03.2015. http://www.haberler.com/toki-baskanituran-aciklamasi-7131317-haberi/.

Tunç. (2011). Bursa'da Yerel Ekonomik Büyümeye dair Koalisyon İnşaası üzerine Eleştirel bir Değerlendirme. In Cumhuriyet Döneminde Bursa'da Kentleşme Sempozyumu 22-23 Eylül Bildiriler Kitabı (Der. Ertürk, H. Dostoğlu, N. and Sam, N.) (pp. 101-122).

Türel, A. (2011). Bursa' da Konut Üretimi. In Cumhuriyet Döneminde Bursa'da Kentleşme Sempozyumu 2223 Eylül Bildiriler Kitabı (Der. Ertürk, H. Dostoğlu, N. and Sam, N.) (pp. 63-80).

Uyan, A. (2008) Kent Merkezlerindeki Konut Alanlarında Çöküntüleşme ve Dönüşüm: Bursa Doğanbey Kentsel Dönüşüm Projesi Örneği. Unpublished master's thesis, Gazi University, Ankara.

White, J. T. (2015). Future directions in urban design as public policy: Reassessing best practice principles for design review and development management. Journal of Urban Design, 20(3), 325-348.

World Bank. (2015). Rise of the anatolian tigers: Turkey urbanization review. Washington, DC: World Bank. Retrieved March 16, 2016, https://openknowledge.worldbank.org/handle/10986/22388. 